\title{
Fertilization of rat oocytes cultured in vitro from various stages of maturation
}

\author{
K. Niwa, M. Miyake, A. Iritani and Y. Nishikawa \\ Department of Animal Science, College of Agriculture, Kyoto University, Kyoto, Japan 606
}

In a previous study, it was shown that nuclear maturation from the germinal vesicle stage to division of the first polar body in rat oocytes could be completed in a defined medium, but that the proportion of oocytes penetrated and cleaved was low (Niwa \& Chang, 1975), perhaps because of some fault in the maturation process. The present study was to determine the number of oocytes penetrated and cleaved in vitro when they were cultured at various stages during maturation in vivo.

White rats of the Wistar strain were used. Immature females (21-25 days old) were induced to superovulate by a s.c. injection of 10 i.u. PMSG (Serotropin: Teikoku-Zoki Co.) $48 \mathrm{hr}$ before an i.p. injection of 10 i.u. HCG (Puberogen: Sankyo Co.). Oocytes were recovered at various times after the HCG injection according to the procedures described by Niwa \& Chang (1975). Nuclear maturation of rat oocytes in vitro and in vivo is completed by $13 \mathrm{hr}$ after injection of HCG (Niwa \& Chang, 1975). Oocytes recovered at and 2, 4, 6, 8 or $10 \mathrm{hr}$ after the HCG injection were therefore cultured for $13,11,9,7,5$ and $3 \mathrm{hr}$, respectively, in a $\mathrm{CO}_{2}$ incubator $\left(5 \% \mathrm{CO}_{2}\right.$ in air at $\left.37^{\circ} \mathrm{C}\right)$ before exposure to preincubated spermatozoa. Two or three females were used in each group and $30-40$ oocytes from each female were cultured in $0.4 \mathrm{ml}$ medium covered with paraffin oil (Nakarai Chemical Co.) in a tissue-culture dish $(35 \times 11 \mathrm{~mm}$ : Toyoshima Seisakusho). Spermatozoa were obtained from the cauda epididymidis of adult rats (200-300 days old) and preincubated at a concentration of $0.3-0.6 \times 10^{6}$ spermatozoa $/ \mathrm{ml}$ for $5-5 \frac{1}{2} \mathrm{hr}$ in a $\mathrm{CO}_{2}$ incubator. The composition and the method of preparation of the medium for sperm suspension, culture of the oocytes and insemination were as described by Toyoda \& Chang (1974).

After incubation for 12,24 or $35 \frac{1}{2}-36 \mathrm{hr}$, the oocytes were mounted in toto, fixed, stained with $0.25 \%$ lacmoid in $45 \%$ acetic acid (Chang, 1952) and then examined for evidence of fertilization. The oocytes containing an enlarged sperm head(s) or a male pronucleus(ei), or which had cleaved with a fertilizing sperm tail(s) in the vitellus, were considered to be undergoing fertilization.

Table 1. Fertilization in vitro of rat oocytes matured in culture from various stages of maturation in vivo

\begin{tabular}{|c|c|c|c|c|c|c|c|c|}
\hline \multirow[b]{2}{*}{$\begin{array}{l}\text { Time of } \\
\text { collection } \\
\text { of oocytes } \\
\text { (hr after } \\
\text { HCG) }\end{array}$} & \multirow[b]{2}{*}{$\begin{array}{l}\text { Period } \\
\text { of } \\
\text { culture } \\
\text { (hr) }\end{array}$} & \multirow[b]{2}{*}{$\begin{array}{c}\text { Time of } \\
\text { examination } \\
\text { (hr after } \\
\text { insemination) }\end{array}$} & \multirow[b]{2}{*}{$\begin{array}{l}\text { No. of } \\
\text { oocytes } \\
\text { examined }\end{array}$} & \multicolumn{5}{|c|}{ No. of oocytes undergoing fertilization } \\
\hline & & & & Total & $\begin{array}{c}\text { With } \\
\text { abnormality* }\end{array}$ & $\begin{array}{l}\text { With male } \\
\text { and female } \\
\text { pronuclei }\end{array}$ & $\begin{array}{l}\text { Meta- to } \\
\text { telophase } \\
\text { of } 1 \text { st } \\
\text { cleavage }\end{array}$ & 2-Celled \\
\hline 0 & 13 & 12 & 74 & 72 & 28 & 44 & 0 & 0 \\
\hline 0 & 13 & 24 & 77 & 51 & 23 & 28 & 0 & 0 \\
\hline 0 & 13 & $35 \frac{1}{2}-36$ & 80 & 60 & 38 & 3 & 7 & 12 \\
\hline 2 & 11 & $35 \frac{1}{2}-36$ & 90 & 72 & 46 & 5 & 8 & 13 \\
\hline 4 & 9 & $35 \frac{1}{2}-36$ & 96 & 78 & 48 & 10 & 3 & 17 \\
\hline 6 & 7 & $35 t-36$ & 101 & 90 & 50 & 20 & 3 & 17 \\
\hline 8 & 5 & $35 \frac{1}{2}-36$ & 110 & 100 & 31 & 19 & 3 & 47 \\
\hline 10 & 3 & $35 \frac{1}{2}-36$ & 60 & 58 & 4 & 6 & 0 & 48 \\
\hline 14 & 0 & $35 \frac{1}{2}-36$ & 71 & 71 & 0 & 2 & 1 & 68 \\
\hline
\end{tabular}

* Ooctyes with enlarged or absent sperm head, only one pronucleus, fragmented or dispersed nuclei.

From the results presented in Table 1, it can be seen that the proportion of oocytes undergoing fertilization was very high $(66-100 \%)$ in those recovered at any stages of maturation and cultured 
in vitro. Although $66-97 \%$ of the oocytes recovered after culture for $13 \mathrm{hr}$ were undergoing fertilization $12-36 \mathrm{hr}$ after insemination, the number undergoing normal fertilization was reduced (37\%) with increasing duration of incubation.

Of the oocytes recovered 2-10 $\mathrm{hr}$ after HCG injection, $80-97 \%$ were undergoing fertilization, which was, however, abnormal in most oocytes (56-64\%) recovered 2-6 hr after HCG injection. Only $18-22 \%$ of oocytes matured in vitro from $2-6 \mathrm{hr}$ after injection of HCG cleaved, but $47-83 \%$ of those matured in vitro from 8-10 hr after HCG injection did so. All the oocytes fully matured in vivo and ovulated were undergoing normal fertilization and $96 \%$ were at the two-cell stage.

In the previous study, only $18-22 \%$ of oocytes from CD strain rats were penetrated and undergoing fertilization after maturation in vitro (Niwa \& Chang, 1975). The improved fertilization rate for oocytes of rats in the present study is unlikely to be due to the strain difference and is most probably related to technical improvement. However, the improved rate of cleavage for oocytes recovered 8-10 hr after $\mathrm{HCG}$ injection is related to the stage of maturation reached in vivo, since first anaphase is reached by $8 \mathrm{hr}$ after injection of HCG (Niwa \& Chang, 1975). It therefore appears that the final stage of fertilization was inhibited if the oocytes were cultured in a defined medium from the stages before anaphase I, although sperm penetration of oocytes matured in vitro from any stages of maturation was possible.

This work was supported by a grant from the Ford Foundation. One of us (K.N.) is a recipient of a grant (No. 076119) from the Ministry of Education of Japan.

\section{References}

Chang, M.C. (1952) Fertilizability of rabbit ova and the effects of temperature in vitro on their subsequent fertilization and activation in vivo. J. exp. Zool. 121, 351-382.

Niwa, K. \& Chang. M.C. (1975) Fertilization of rat eggs in vitro at various times before and after ovulation with special reference to fertilization of ovarian oocytes matured in culture. J. Reprod. Fert. 43, $435-451$.

Toyoda, Y. \& Chang, M.C. (1974) Fertilization of rat eggs in vitro by epididymal spermatozoa and the development of eggs following transfer. J. Reprod. Fert. 36, 9-22. 